\title{
THE MYCENAEAN PALATIAL ECONOMY: MAKING THE MOST OF THE GAPS IN THE EVIDENCE ${ }^{1}$
}

It has long been recognised that the Linear $B$ archives from the Mycenaean palaces of Late Bronze Age Greece document 'a massive redistributive operation, in which all personnel and all activities, all movements of both persons and goods ... were administratively fixed'. ${ }^{2}$ Goods, land and services were transferred within the extensive territory of each palace without the equivalences of value between commodities which are a prerequisite of market exchange. ${ }^{3}$ The transactions recorded in the Linear B archives are thus unambiguously 'redistributive', an Aegean variant of a form of exchange widespread in the ancient civilisations, and as such have attracted the interest both of economic historians ${ }^{4}$ and of prehistorians concerned with the development of complex society. ${ }^{5}$ The term 'redistribution' embraces a range of possible forms, however, and in the case of the Mycenaean palaces poses a number of questions.

\section{Redistribution: the problems}

\section{Type of redistribution 6}

At one extreme, the palaces may have collected produce or skills from particular localities or persons and literally redistributed or 'pooled' these among other localities or persons. ${ }^{7}$ At the other extreme, palatial redistribution may simply have served to 'mobilise' resources for consumption by the elite and their servants. ${ }^{8}$ Mobilisation economies may also provide some services to the subordinate population, ${ }^{9}$ however, and the pooling of local surpluses and deficits (rather than local specialisations) has been emphasised as one possible function of palatial redistribution in Greece. ${ }^{10}$ In other words, palatial redistribution may have combined pooling and mobilisation.

\section{Currency}

It has been argued that the Mycenaean palaces practised an extreme form of 'staple finance': each commodity was separately collected and redistributed, with no evidence that obligations in one commodity could be paid in another. This contrasted with Alalakh, where conversion between commodities was possible, 
though not between the staple and prestige/silver spheres of exchange, and with ancient Mesopotamia, where even grain and silver could be exchanged. " Convertibility between bulky staples and low-volume, high-value prestige goods may have enabled early states to mobilise staple resources from large territories by 'wealth finance'. ${ }^{12}$ The possibility of a similar use of prestige goods by the Mycenaean palaces must also be considered: despite the general absence of overt equivalences of value between commodities in the Linear B archives, there is possible indirect evidence of such equivalences ${ }^{13}$ and there are rare references to 'buying'. ${ }^{14}$ The existence of separate staple and prestige spheres of exchange in other cultures is also a complex and problematic issue. ${ }^{15}$

\section{Scope}

One critical issue which the Linear $\mathbf{B}$ archives do not directly resolve is the extent to which the palaces controlled and recorded all economic activity within their territories..$^{16}$ If the palaces exercised only partial control, which aspects of the economy or which parts of their territories were not centrally directed? And was this independent economic activity conducted on the basis of reciprocity, or through a series of local redistributive systems, or did it constitute a separate sphere of market exchange as has been suggested for other ancient civilisations. ${ }^{17}$

\section{Mobilisation and production of surplus}

In the case of Bronze Age Greece, it has been tacitly assumed by some authors that the surplus which supported the palaces was raised indirectly as some sort of levy on the agricultural produce of the subject population. ${ }^{18}$ On the other hand, it has been argued that early states were often directly financed from the produce of large estates owned by the elite. ${ }^{19}$ Furthermore, although considerable quantities of staple resources can be mobilised by collating and redeploying the 'normal surplus' regularly accrued by individual households as a safeguard against subsistence failure ${ }^{20}$ it is usually assumed that the palaces were supported by additional production. ${ }^{21}$ Additional production has in turn been accounted for in terms of agricultural innovation (e.g. introduction of the olive and vine) ${ }^{22}$ or intensification (of capital, land or labour). ${ }^{23}$ The direct production of surplus on large elite estates, on the other hand, may have entailed the adoption of more extensive rather than intensive husbandry practices. ${ }^{24}$

This paper attempts to resolve some of these problems. The argument is developed in three stages: first by reviewing the archival evidence, secondly by considering the archaeological evidence and the contradictions between this and the archival record, and thirdly by using analogy with present-day rural economy 
to explore some apparent lacunae in both the foregoing data sets. For the purpose of this exercise, two simplifying assumptions are made: first that, despite differences in developmental history, the Mycenaean palaces of Late Bronze Age Crete and mainland Greece were basically similar institutions; secondly that the Linear B archives, though largely derived from a single year at each palace, are broadly representative of the Mycenaean palatial period as a whole. In addition, it is acknowledged that 'gaps' in the archival record, and contradictions between the archival and archaeological evidence, do not necessarily reflect partial preservation or imperfect interpretation, but may be an indication of the different and partial scope of each type of evidence. ${ }^{25}$

\section{Archival evidence}

The Linear B archives, comprising inventories of palatial resources (in goods, land and personnel) and records of the movement of these resources to, from and within the palatial system, ${ }^{26}$ document four principal types of transaction.

\section{Taxation}

The palaces levied 'taxes' in a range of (mostly) non-staple commodities - spices, dye plants, hides, wood, flax, olive oil, honey and perhaps metals and plain cloth. ${ }^{27}$ Some labour services may have been exacted on the same basis. ${ }^{28}$ The absolute tax assessment for individual districts was variable, but the relative proportions of contributions in different commodities were fixed ${ }^{29}$ and the taxation records provide no evidence of local specialisation. ${ }^{30}$ The palace at Pylos monitored local conditions sufficiently closely to allow tax reductions, perhaps in recognition of services rendered to the centre, to particular community members ${ }^{31}$ and to record the identity of individuals expected to contribute (or excused from contributing) flax in respect of land which they held ${ }^{32}$ Similarly, the palace at Knossos may have exacted modest quantities of certain aromatic plants in respect of land allocated to groups of men. ${ }^{33}$ For the most part, however, taxation was decentralised and the palace took no interest in the production of the relevant commodities ${ }^{34}$ For example, well over a hundred toponyms are recorded in the Pylos archives and a similar number of settlement sites is known from archaeological reconnaissance within the probable territory of the palace, ${ }^{35}$ but the collection of taxes was organised by regional or local sub-centres. ${ }^{36}$ Finally, similarities between the different archives, in both the proportional assessment of commodities ${ }^{37}$ and the method of book-keeping, ${ }^{38}$ suggest that it is valid to treat the Mycenaean palaces of mainland Greece and Crete as essentially similar institutions. 


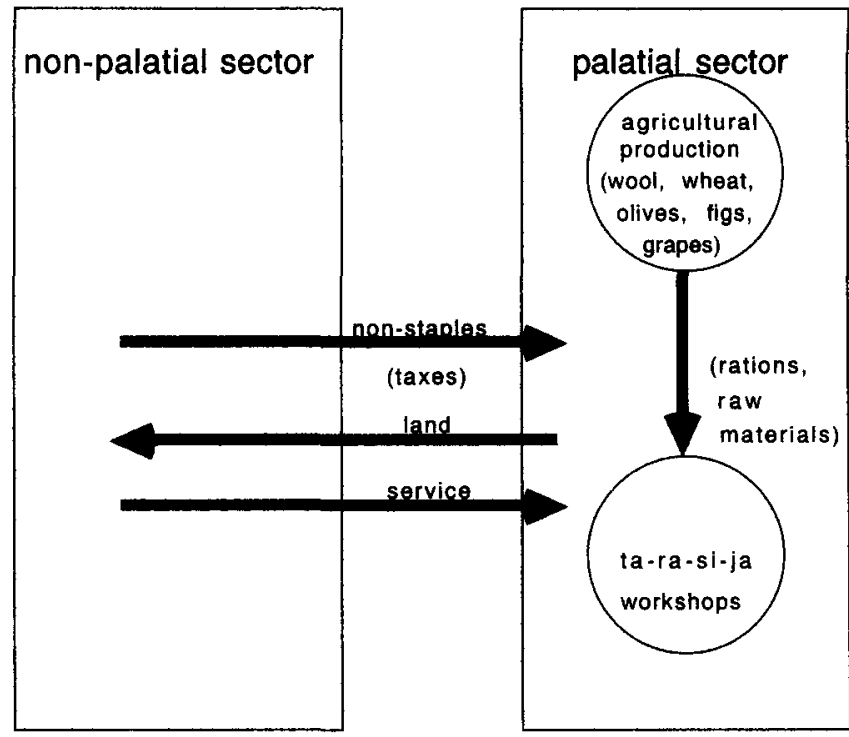

external trade

key

archival evidence (regular, obligatory transactions)

Fig. 1 The Mycenaean palatial economy: principal transactions attested by archival evidence.

\section{Agricultural production}

The archives are most informative on livestock, listing large numbers of goats, pigs, cattle (including working oxen), horses, donkeys and especially sheep. ${ }^{39} \mathrm{It}$ is clear that most of these animals were not 'owed' or 'paid' to the palace but were in some way directly controlled or owned by the palace. ${ }^{40}$ For example, the Knossos archives record some $80,000-100,000$ sheep, of which more than 60,000 were kept for wool production. ${ }^{41}$ About one-third of these wool sheep (those assigned to the high-ranking 'collectors') ${ }^{42}$ may have been subject to some form of shared ownership or control, but the palace centrally directed stock replenishment from separate breeding flocks and centrally set and monitored production targets in wool and lambs. ${ }^{43}$

Although the archives are substantially less informative on crops than livestock, the absence of reference to pulses is surprising. ${ }^{44}$ The grain crops mentioned are 'wheat' and 'barley', but the latter is recorded in relatively small amounts and mostly occurs as religious offerings ${ }^{45}$ Moreover, records of 'wheat' must surely refer either to free-threshing wheat (presumably bread wheat) or to glume wheat (emmer or einkorn): as the former was apparently stored as free grain and the 
latter in the much bulkier form of partially threshed spikelets, ${ }^{46}$ it is implausible that volume measurements of the two types were not distinguished. ${ }^{47}$ Thus palatial interest in grain crops was highly specialised..$^{48}$

'Wheat' is documented in substantial quantities and, although some records almost certainly represent measurements of land area, ${ }^{49}$ others represent issues or receipts of grain and a few records of receipts refer to harvesting. ${ }^{50}$ Evidently the palace was directly involved in the production of at least some wheat. The palace also kept records of orchards (apparently including 'nurseries'), noting both the area of land and the number of vines and figs planted in such detail as to suggest palatial ownership, ${ }^{51}$ while the association of some substantial olive receipts with 'wheat' harvest records suggests central involvement in this aspect of agricultural production too..$^{52}$ Whereas palatial livestock (particularly wool sheep) were widely distributed within the territory of each palace, however, palatial agriculture seems to have been strongly concentrated in the vicinity of the palaces and of major sub-centres. ${ }^{53}$

\section{Maintenance of palace staff}

The archives document two rather different forms of support to palatial staff: fully-dependent (and presumably full-time) servants and craft-workers were supported directly by the issue of food rations, ${ }^{54}$ while semi-dependent senior officials and skilled craftsmen were supported indirectly with allocations of land. ${ }^{55}$ At Pylos, the number of palatial dependents may have totalled ca. 4,000, of whom about one-third (including female textile workers and palace servants), drew food rations and two-thirds (including bronzesmiths, soldiers, hunters and planters) received land allocations ${ }^{56}$ In addition, officials may have been allocated particular types of cloth or skin as a mark of their rank. ${ }^{57}$

\section{Craft production}

Both fully- and semi-dependent craft-workers worked under the 'tarasija' system, receiving measured supplies of raw materials from the palaces and being set centrally regulated production targets. Goods produced under this system, which involved a very high level of specialisation, ${ }^{58}$ included bronzes, chariots, textiles and probably weapons, furniture, leather items and perfumed olive oil. ${ }^{59}$ Other crafts, represented by archival references to the relevant specialists, include the working of gold and glass-paste. ${ }^{60}$ The palaces kept inventories of their stockpiles of finished craft goods or 'treasury'. ${ }^{61}$

In addition to these four types of transaction, the Linear B archives document religious offerings originating in the palaces ${ }^{62}$ and also record divine or religious property $^{63}$ and probably monitor offerings originating outside the palatial 
system. ${ }^{64}$ The sanctuaries so documented were evidently under palatial control, ${ }^{65}$ however, and transactions involving them are treated here as an integral component of the palatial economy. ${ }^{66}$ These transactions take three principal forms, each of which has already been documented within the palatial economy: first, offerings, land allowances and rations given to the gods and to their priests presumably supported religious specialists and their subordinate staff; ${ }^{67}$ secondly, issues of subsistence rations and raw materials supported further craft production; ${ }^{68}$ thirdly, land belonging to a particular deity or sanctuary was allocated to craft specialists and other personnel in return for both agricultural produce and service. ${ }^{69}$ For the sake of simplicity, therefore, religious offerings may be subsumed under the previous headings of 'agricultural production', 'maintenance of palace staff' and 'craft production'. In addition, offerings directed by the palace to apparently distant sanctuaries may have served to channel some of the resources acquired through taxation back to the local communities. ${ }^{70}$ Some sanctuaries also seem to have been associated with festivals and, on such occasions, it is possible that meat from sacrificed animals was similarly redistributed. ${ }^{71}$

Taken as a whole, the archives reveal three important characteristics of the documented palatial economy. First, the recurrent formula of assessmentpayment-deficit (if any) and the frequent occurrence of deficits from the previous year $^{72}$ show that the archives were, for the most part, annual records of regular, obligatory transactions. ${ }^{73}$ Secondly, the degree of palatial control over the economy was very variable, apparently ranging from decentralised taxation of a range of non-staples to centralised production of agricultural staples in the vicinity of major centres and sub-centres. Thirdly, the archives provide no information on the acquisition of several exotic raw materials used by palatial craft specialists, such as tin and ivory. ${ }^{74}$ Similarly, apart from a few religious offerings and some hints of allocations to high-ranking officials and diplomatic gifts, ${ }^{75}$ they shed little light on the disbursement of the finished products. These and other lacunae are to some extent redressed by the archaeological evidence.

\section{Archaeological evidence}

The remains of the palaces themselves confirm many of the general conclusions drawn from the archival evidence. The size and architectural sophistication of these complexes indicates the mobilisation both of a considerable labour force and of an impressive range of specialist skills. The contents of the constituent rooms confirm palatial involvement in large-scale storage, craft production and administration and demonstrate palatial incorporation of religious authority. ${ }^{76}$ In addition, the archival evidence for palatial craft production has been confirmed or elaborated by archaeological evidence: for stone and bronze working and the manufacture of perfumed oil in the palace at Pylos; ${ }^{77}$ for the working of 


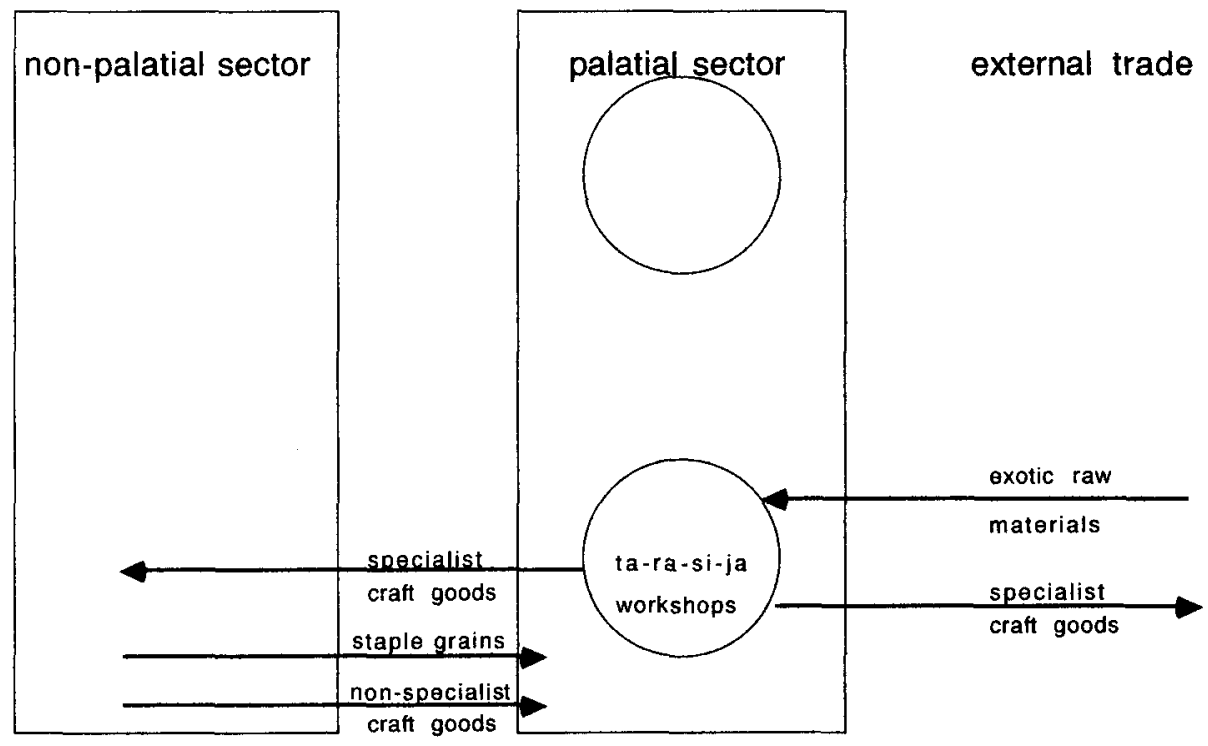

key

archaeological evidence (irregular transactions?)

Fig. 2 The Mycenaean palatial economy: principal transactions attested by archaeological evidence.

ivory, gold, copper, opal, steatite, quartz, rock crystal and glass at Mycenae; ${ }^{78}$ for the working of gold, rock crystal, lapis lazuli, onyx, agate, ivory and perhaps glass at Thebes; ${ }^{79}$ and for the manufacture of stone vases and of stone and gold seals at Knossos. ${ }^{80}$

Archaeological evidence also serves to document three important types of transaction on which the archives are more or less silent.

\section{Disbursement of palatial craft goods}

Ornaments of metal, semi-precious stone and glass-paste, such as were made in the workshops of the palaces at Mycenae and Thebes, have been widely found in tombs in southern Greece, ${ }^{81}$ suggesting that these percolated at least some way down from the highest echelons of palatial society. ${ }^{82}$ The same is true of small, fine-ware stirrup-jars, ${ }^{83}$ suitable for holding perfumed oil. ${ }^{84}$ In addition, the numerous stirrup-jars of Aegean origin found particularly in the east Mediterranean ${ }^{85}$ presumably carried perfumed oil made in palatial workshops. Palatial textiles are much less amenable to archaeological preservation, but earlier Minoan examples may well be depicted in Egyptian wall paintings. ${ }^{86}$ 


\section{Non-palatial production}

The palace at Pylos consumed huge quantities of plain cooking and table ware, apparently from more than one source, ${ }^{87}$ as well as containers for perfumed oil and wine and a variety of very fine vessels used in elite contexts. Potters are scarcely mentioned in the archives, ${ }^{88}$ however, so much of the abundant pottery found in the palaces was presumably made in the non-palatial sector.

Bio-archaeological studies also demonstrate the relatively diverse nature of non-palatial agriculture. Whereas the archives are overwhelmingly concerned with one type of wheat, charred crop remains from non-palatial contexts point to a wide range of pulses and cereals (including both free-threshing and glume wheats). Since charred remains from palatial assemblages are equally diverse, it seems that a range of seed crops produced in the non-palatial sector was imported to the palaces. ${ }^{89}$ Similarly, the limited archaeozoological evidence from both palatial and non-palatial contexts indicates a more balanced mixture of domestic animals than do the archives with their heavy emphasis on sheep ${ }^{90}$ and this discrepancy implies that the palaces either exported large numbers of sheep or imported substantial numbers of cattle, goats and pigs. Finally, the number and size of settlements revealed by archaeological surface reconnaissance indicates that the palatial dependents recorded in the archives were just a small fraction of the available regional labour force. ${ }^{91}$

\section{Long-distance 'trade'}

Archaeological finds have confirmed and elaborated the range of exotic raw materials known to have been used by palatial craftsmen, while archaeometry is beginning to clarify the source of some of these imports. ${ }^{92}$ Archaeometry also demonstrates the movement between different regions of Greece of large, coarseware stirrup-jars, presumably carrying unperfumed oil for use in the palatial workshops. ${ }^{93}$ Finds of both exotic raw materials and coarse-ware stirrup-jars are strongly concentrated in the major palatial centres, suggesting a pre-eminent role for the palace in such transactions, ${ }^{94}$ while the hoard of oriental seals from Thebes and faience tiles with pharaonic cartouches from Mycenae confirm the archival hints that at least some of these transactions took the form of diplomatic gifts. ${ }^{95}$ Excavations of shipwrecks show that single vessels of very modest size could have carried the small quantities of imports actually documented, ${ }^{96}$ while even the most impressive concentration of Aegean pottery found in the east Mediterranean could have been introduced by the odd diplomatic mission. ${ }^{97}$ The striking artistic and architectural similarities between palaces and elite tombs from different regions of Greece $^{98}$ also indicate the movement of 'master craftsmen' between different polities and this too may have taken place in the context of diplomatic exchanges. ${ }^{99}$ 
Comparison of the archival and archaeological evidence suggests that a wide range of agricultural and craft production took place outside palatial control and that a range of commodities entered or left the palaces without being recorded by the Linear B bureaucracy. If, as has been suggested, Linear B was primarily used to monitor the fulfilment of regular obligations, these unrecorded flows of commodities may well represent irregular, non-obligatory transactions. The layout of the palace at Pylos may shed some light on how these transactions took place. The archive rooms 7-8 were located at the 'tradesman's entrance' through which outsiders could have gained access to a courtyard and thence to the throne room itself. ${ }^{100}$ Adjacent to the archive rooms was a 'waiting room' with an attached pantry containing perhaps 500-600 plain-ware drinking cups. ${ }^{101}$ The number and simplicity of these cups hints at some form of widespread hospitality ${ }^{102}$ and so at direct palatial interaction with a significant number of fairly lowranking persons. Since most redistributive transactions were conducted through administrative sub-centres or supervising officals, ${ }^{103}$ these plain cups perhaps indicate a mask of gift exchange for subjects seeking an audience in connection with irregular, non-obligatory transactions.

Archaeological evidence is also the principal source of information on some important diachronic developments, ${ }^{104}$ such as the long-term changes in palatial provision for bulk storage ${ }^{105}$ and the progressive concentration of craft production at the palatial centres. ${ }^{106}$

\section{Analogy with present-day rural economy}

Consideration of present-day rural economy suggests possible additional insights into three aspects of palatial agricultural economy: cereal production, sheep raising, and agricultural risk and risk-buffering.

\section{Cereal production}

It has been argued elsewhere that the heavy predominance of cereals over pulses in recent Greek agriculture partly reflects the concern of farmers, who are producing on a large scale to supply urban markets, to avoid the higher labour costs of growing pulse crops. ${ }^{107}$ Conversely, the relatively even representation of cereals and pulses in the archaeobotanical record for Neolithic and Bronze Age Greece suggests the prevalence of more intensive methods (including cereal/pulse rotation) consistent with cultivation on a small scale. ${ }^{108}$ On this basis, the contrasting archaeobotanical and archival evidence from the Late Bronze Age suggests the prevalence of 'small-holding' in the non-palatial sector, with the palaces specialising in the production of 'wheat' on extensively farmed 'estates'.109 This is consistent with the discovery of weed seeds reminiscent of extensive field agriculture in two samples of grain from palatial Mycenae ${ }^{10}$ and with a weed 


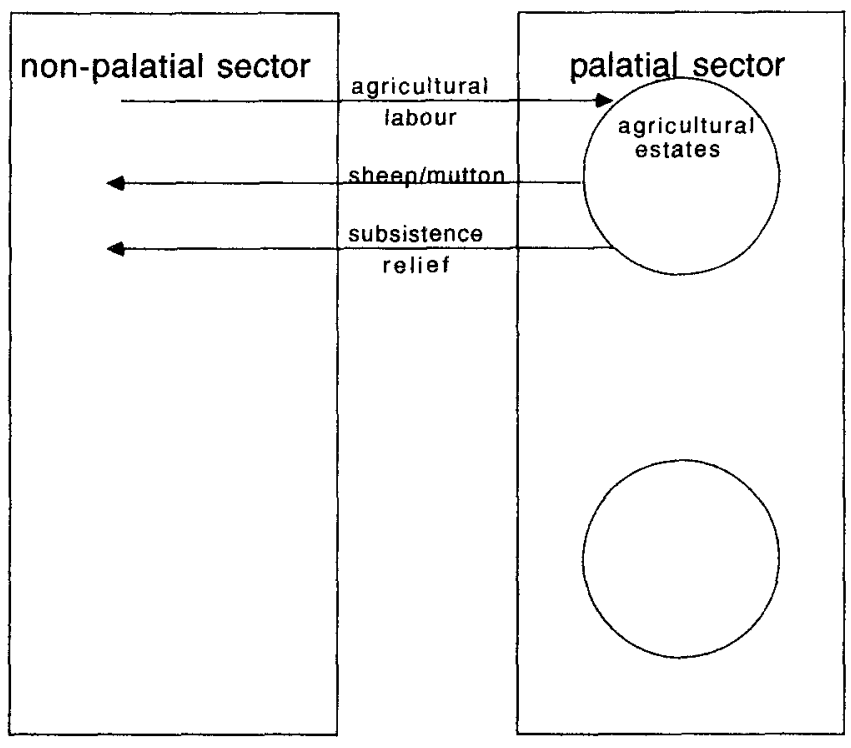

external trade

key

analogical evidence (irregular transactions?)

Fig. 3 The Mycenaean palatial economy: principal transactions attested by analogical evidence.

flora more suggestive of garden cultivation in the large grain-storage complex at non-palatial Assiros Toumba in northern Greece. 111 This suggested contrast between palatial and non-palatial land-use could potentially be tested by further studies of the weeds of Late Bronze Age crops. ${ }^{112}$

The key to surplus production with extensive methods lies not in securing high yields per unit area, but in farming large areas with low inputs of human labour. ${ }^{113}$ The archives certainly document some substantial palatial landholdings. At Pylos, for example, the royal temenos of perhaps 15 ha. (GRA 30) and the 5-ha (GRA 10) holding of the lawagetas ${ }^{14}$ are large enough to warrant extensive methods of farming. ${ }^{115}$ Plough animals are critical to extensive agriculture, allowing large areas to be tilled and sown with a small human labour force, and the Knossos archives record palatial control of several dozen pairs of working oxen. ${ }^{116}$ At Pylos, records of working oxen have not been found, ${ }^{117}$ but individual palatial estates (both secular and religious) amounted to various multiples of 5 ha. (GRA 10), ${ }^{118}$ and 5 ha. is approximately the area which can be ploughed each winter by one pair of oxen. ${ }^{119}$

In traditional extensive agriculture, fallowing plays an important role in weed control, ${ }^{120}$ avoiding the need for a large human labour force, and also provides an 
opportunity for grazing animals to manure the fields. In the Knossos archives, areas of high arable potential such as the Mesara plain are associated not only with the largest numbers of sheep but also with the largest individual flocks. ${ }^{121}$ Since these sheep all effectively 'belonged' to the palace, flock size was probably determined by the size of the parcels of pasture land on which they were grazed. ${ }^{122}$ The association of large flocks with areas of high arable potential, therefore, suggests the existence of large blocks of fallow available for grazing. The association of cereals and olives in harvest records from Knossos ${ }^{123}$ is also compatible with this suggestion, as a cereal/fallow rotation integrates well with the intercropping of cereals and olives. ${ }^{124}$

The large harvests recorded in the archives are also compatible with extensive estate agriculture. Even the massive ca. 800-ton 'wheat' harvest from Dawo in the Mesara plain ${ }^{125}$ could plausibly represent the total yield from less than 1,000 ha. $\left(2,000\right.$ ha. with alternate fallow), ${ }^{126}$ requiring the use of less than 200 pairs of oxen. ${ }^{127}$ These estimates of both land and working oxen are not inconceivable for a major palatial estate or perhaps group of estates., ${ }^{128}$

On the other hand, the Dawo harvest is most unlikely to represent a levy on non-palatial agriculture. For example, a 'tithe' (i.e. one-tenth levy) ${ }^{129}$ would imply the harvest of 'wheat' fields covering ca. 10,000 ha. With regular fallowing or intercropping with olives, this figure could rise to $20,000 \mathrm{ha}$. or more, an area equivalent to the whole Mesara plain. ${ }^{130}$ Whereas palatial agriculture was highly specialised in 'wheat', however, the archaeobotanical evidence suggests that, in non-palatial agriculture, 'wheat' occupied only a minority of the area sown in cereal and pulse crops. As a tithe just on non-palatial 'wheat' production, therefore, the Dawo harvest would have been collected from perhaps the whole of central Crete - an implausibly large area. ${ }^{131}$

Thus there is persuasive, if indirect, evidence that the palaces produced 'wheat' on large, extensively farmed estates. ${ }^{132}$ While the use of oxen for ploughing and the substitution of fallowing in the place of manual weeding may have minimised the amount of human labour needed during winter and spring for 'wheat' growing, a massive labour force will still have been necessary in early summer for reaping and subsequent processing of the harvest. The Dawo 'wheat' harvest will have entailed something in the order of 20,000 man-days just for reaping, ${ }^{133}$ and perhaps as much again for stooking, transporting, threshing and winnowing. ${ }^{134}$ Moreover, if only one type of wheat was involved and if it was indeed produced within just part of the Mesara plain, the crop will all have ripened more or less simultaneously and the period available for reaping will have been very brief. The palace of Knossos could certainly have mustered a harvest gang of, say, 1,000 reapers for 20 days, by mobilising much of its dependent workforce. ${ }^{135}$ There is no hint of this arrangement in the archival records of dependent personnel, however, suggesting that harvesting and processing labour may have been drawn from outside the palace's dependent workforce. ${ }^{136}$ 


\section{Sheep raising}

The palace of Knossos controlled 60,000 or more wool sheep. By analogy with English medieval sources, Killen has argued that these sheep would have been replaced at about 5-6 years of age, ${ }^{137}$ implying an annual replacement rate of ca. $17-20 \%$ or an annual total of at least $10,000-12,000$ new wool sheep. These expectations are remarkably close to the $19 \%$ incidence of 'yearlings' ( $p e$ lambs) in flock records which make this distinction ${ }^{138}$ and to the 11,900 lambs (ne rams) recorded at Amnisos. ${ }^{139}$ The ratio of males to females in the wool flocks is ca. 8 : $1,{ }^{140}$ compared with a ratio of ca. $1: 1$ among new-born lambs. On this basis, the $10,000-12,000$ yearlings drafted into the wool flocks each year imply some 20,000 breeding ewes. ${ }^{141}$ This is substantially more than the number of breeding ewes actually recorded and could reflect particularly poor preservation of breeding flock records ${ }^{142}$ or, perhaps, a substantial contribution to the replenishment of palatial wool flocks from the non-palatial sector.

Something like 10,000-12,000 sheep must also have been removed from the Knossos wool flocks each year, either dying or being culled. The number of sheep recorded as missing $(o)$ or old $(p a)^{143}$ amounts to only a small fraction of this total, ${ }^{144}$ perhaps because the annual culling and flock replenishment took place at the time of an earlier (autumn) census and so do not feature in the surviving records apparently compiled in spring. ${ }^{145}$ Conversely, the Pylos archives dealing with palatial wool flocks do record the collection of large numbers of old sheep and their replacement with young stock. ${ }^{146}$ Neither archive, however, reveals what happened to the culled wool sheep. An annual consumption of 10,000 12,000 sheep (documented natural mortality is very low) by the Knossos elite or the gods would be an impressive achievement, rendered even more improbable by the considerable number of bulls, sheep and fattened pigs also destined for sacrifice or elite feasting. ${ }^{147}$ Redistribution of these sheep to the palace's dependent workforce would surely have been registered in the detailed ration documents. The transfer of substantial numbers of culled wool sheep (or substantial quantities of mutton) to the non-palatial sector is arguably the most likely outcome and, as has already been noted, is consistent with the available faunal evidence.

\section{Agricultural risk and risk-buffering}

Agricultural yields are inevitably variable and, in the semi-arid south of Greece, farmers will periodically have faced serious shortfalls of staple crops. In recent times, farmers in Greece have taken a variety of measures to cushion themselves against shortage, such as growing a range of crops with different climatic tolerances, overproduction of staples and storage of the resultant surplus, building up a small herd ('animal capital') to be sold in time of need, and the 
exchange of cash crops, craft goods or labour for staples. ${ }^{148}$ Late Bronze Age farmers in the non-palatial sector may well have grown a range of different crops and kept a mixture of livestock, ${ }^{149}$ but other traditional methods of risk-buffering may have been curtailed by the palaces. The palaces may, by controlling land, have restricted the opportunities for ordinary farmers to overproduce and, by consuming significant quantities of cereals and pulses produced in the nonpalatial sector, will have reduced the potential for domestic storage of surplus. The massive sheep flocks run by the palaces will have competed with household flocks for herding labour and pasture ${ }^{150}$ and may also have drawn heavily on the non-palatial sector for their replenishment. Production of some craft goods, notably ceramics, took place in the non-palatial sector, but the more specialised crafts seem to have been a palatial monopoly ${ }^{151}$ and the palaces must also have used considerable external labour for harvesting, crop processing and herding. With domestic buffering mechanisms so thoroughly undermined by the palatial economy, the survival of ordinary farmers through bad harvests must surely have depended on assistance from the central authorities.

Central provision of relief is not directly attested in the archives, but at Knossos documented income of harvested 'wheat' exceeds documented outgoings in rations to permanent craft-workers and servants. ${ }^{152}$ Although both sets of figures are incomplete, cereals and pulses 'imported' from the non-palatial sector may have boosted central grain supplies significantly and so the palace may well have had the capacity to supply subsistence relief in the form of grain. The thousands of sheep culled each year from the wool flocks could also have contributed to the relief of shortage: livestock can be moved to where food is needed more easily than grain, and sheep are particularly valuable in this respect because of the high fat content of mutton. ${ }^{153}$ If the use of mutton as the main source of calories requires the slaughter of ca. 20 sheep/person/year, ${ }^{154} 10,000$ culled wool sheep could have fed something like 500 people for a year or 2000 for 3 months and so could have made a significant contribution to subsistence relief. ${ }^{155}$

Recipients of subsistence relief may have 'repaid' the palace with other commodities, such as metal, linen or oil (see below), or with labour. Some of the long-term obligations of service recorded in the archives may ultimately have been incurred in this way, ${ }^{156}$ while temporary labour services may have been provided to the palace in return, perhaps, for more modest assistance. For example, in addition to the regular issue of rations to full-time palatial employees, rations were provided to others on an ad hoc basis in return for services rendered to the palace. ${ }^{157}$ It has also been argued that additional, seasonal labour was needed to harvest the palatial 'wheat' crop. If such work was rewarded in kind in the field or at the threshing floor, the palace 'harvest' records might represent grain brought into store after deduction of harvesting costs. ${ }^{158}$ Any grain issued in this way would not feature in recorded disbursements from 
palatial stores. Alternatively, recipients of relief may have worked for the palace for a whole year as shepherds. Shepherds may have been unusual among dependent palatial personnel in receiving neither food rations nor allocations of land. ${ }^{159}$ Moreover, lambing and wool production targets set for palatial flocks make no allowance for inevitable fluctuations in yields, ${ }^{160}$ suggesting that shepherds may have been expected to make up deficits from their own livestock. Since shepherds apparently stood only to lose from taking on such herding 'contracts', it is plausible that they were working off obligations to the palace. ${ }^{161}$

\section{Synthesis: patterns of exchange in the Mycenaean palatial economy}

Evidence, direct or indirect, has been adduced for the movement of a variety of goods and services to, from and within the Mycenaean palatial economy.

\section{Within the palatial sector}

The archives record direct palatial production of agricultural staples or raw materials, notably of 'wheat', olives, figs, grapes and wool; the issuing of rations to low-ranking servants and artisans; the issuing of raw materials to palatial workshops and subsequent collection of the finished products. Linear B records of these transactions monitor the assessment and fulfilment of redistributive obligations to or from the centre.

\section{Between the palace and other polities}

The import of raw materials for the palatial workshops and export of the finished products are not documented in Linear B and so probably represent irregular, opportunistic transactions. There are hints in the archives that some of these craft goods may have been classified as 'guest gifts', but it is clear from Near Eastern diplomatic correspondence of the period that quite hard-nosed exchanges of commodities could be dressed up as elite gift exchange. ${ }^{162}$ It is likely that, in one guise or another, palatial craft goods were exchanged in return for imported raw materials.

3. Between the palace and the non-palatial sector

Documented transactions, in fulfilment of regular obligations, include the decentralised collection of taxes in non-staple commodities, grants of land and records of service. In some cases, service to the palace is linked to grants of land or to tax allowances for the community concerned. ${ }^{163}$ Undocumented transac- 

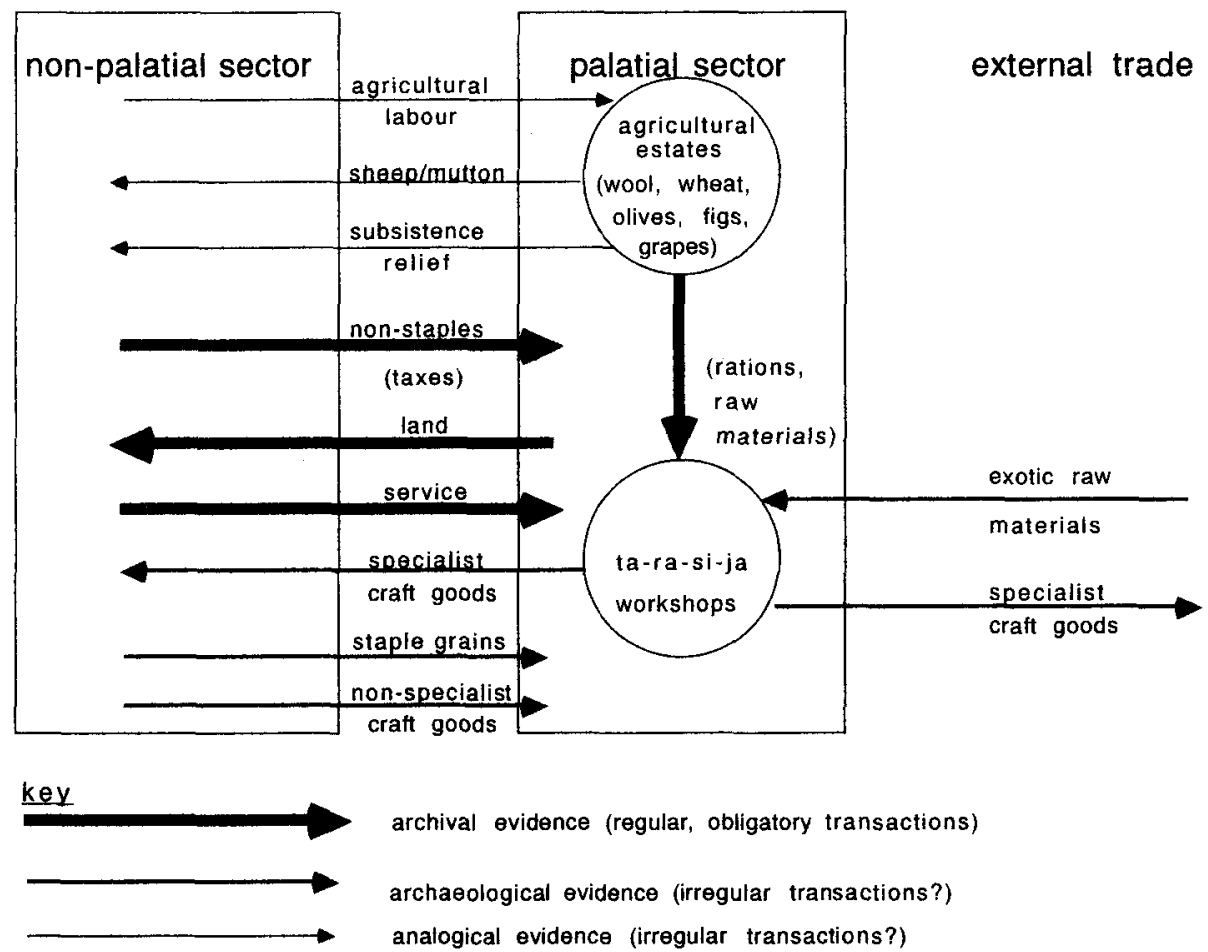

archival evidence (regular, obligatory transactions)

archaeological evidence (irregular transactions?)

anatogical evidence (irregular transactions?)

Fig. 4 The Mycenaean palatial economy: principal transactions attested by archival, archacological and analogical evidence.

tions (presumably not in fulfilment of regular obligations) arguably included the flow to the palace of agricultural labour, staples and relatively unspecialised craft goods and the reciprocal movement to the non-palatial sector of specialised craft goods and subsistence relief. Whatever the overt form of these transactions (there are hints of some ceremony from the Pylos pantries), it again seems likely that the palace gave out prestige and subsistence goods in return for goods and services received from the non-palatial sector. Some empirical support for this suggestion is provided by two possible references to the palace buying linen textiles with 'wheat' and bronze respectively ${ }^{164}$ and buying alum with wool, wine etc. ${ }^{165}$ The relative rarity of these purchase records should not be taken as an indication that such transactions were exceptional. Although all the Linear B clay tablets were temporary documents, most regular redistributive transactions may have been more or less permanently represented in the archives - either by temporary records of assessments or by periodically updated records of payments and outstanding debts. ${ }^{166}$ If purchase transactions were irregular, however, they may 
only have been recorded where the purchasing office had to authorise another office to make the appropriate payment. ${ }^{167}$ In this case, surviving purchase records may be restricted to transactions which were actually taking place at the time of the destruction of the palaces.

\section{Within the non-palatial sector}

Widespread exchange within the non-palatial sector is implied by the ubiquitous distribution of wheel-made pottery, surely the product of craft-specialists but not apparently made under palatial control. Household produce, both agricultural and craft, will surely have been exchanged within the non-palatial sector and palatial craft goods may also have circulated. At a local level, such transactions may have taken place on the basis of reciprocity, but the broad spatial distribution of weights within Late Bronze Age settlements, in domestic as well as palatial contexts, suggests an important role for exchange. ${ }^{168}$ Indeed, in the Pylos archives, the tax assessments of individual sub-centres included such small and disparate numbers of certain indivisible commodities (e.g. 17 pieces of commodity A, seven oxhides and four units of commodity E) that sharing of this burden may have been impracticable without some sort of prior exchange in different commodities among liable tax-payers. ${ }^{169}$

\section{Conclusions}

In conclusion, an attempt will be made to answer, in reverse order, the questions posed at the outset of this paper.

\section{Mobilisation and production of surplus}

The Mycenaean palaces were financed both directly, from the produce of extensively farmed estates controlled by the elite, and indirectly, by exchanging palatial craft goods for surplus produce from the non-palatial sector.

\section{Scope}

The palaces exercised only partial control over economic activity within their territories: the palaces directly controlled only a small fraction of the total labour force, palatial crop production was concentrated in the vicinity of major centres and sub-centres, and several commodities were only produced in the non-palatial 
sector. Furthermore, exchange rather than redistribution seems to have been the basis on which many goods and services moved between the palatial and nonpalatial sectors (and within the latter). Indeed there is an impressive amount of circumstantial evidence that the fixed proportions in which different commodities were taxed by the palaces encode a customary set of equivalences or exchange rate between staples (including grain) and valuables (including bronze). ${ }^{170}$ These equivalences, which were almost certainly not used in recorded redistributive transactions, ${ }^{171}$ presumably refer to the sphere of irregular, unrecorded exchanges. Fixed equivalences of value mean that the non-redistributive sphere of exchange was merely characterised by 'market elements', as has been suggested for second-millennium B.C. Mesopotamia, and not by price-making markets. ${ }^{172}$

\section{Currency}

Although the Linear B archives record an extreme form of staple finance, archaeological evidence suggests that wealth finance also played an important role: agricultural staples and prestige craft goods were exchanged between the palatial and non-palatial sectors, either directly for each other or indirectly in return for labour services. The concentration of major groups of fully dependent artisans at palaces and sub-centres, ${ }^{173}$ and so near to the palatial estates where bulky agricultural staples were produced, will have facilitated the distribution of rations and raw materials as well as the supervision of craft production. These artisans used raw materials (notably wool) from much further afield, and the palaces may have used their finished products to reward services from the whole of their dependent territories (below). Wealth finance may have played an important role, therefore, in the economic and political integration of an early state ill-equipped in terms of transport technology for the movement of bulky staple resources over long distances. ${ }^{174}$

\section{Type of redistribution}

The palatial taxation system, in which each community contributed the same commodities in the same proportions, is the exact opposite of classic redistribution or 'pooling'. Such indications of geographical specialisation as exist seem to reflect differential treatment, for administrative convenience, of core and peripheral districts rather than exploitation of local variation in the availability of resources. ${ }^{175}$ The overt (i.e. archivally documented) function of palatial redistribution was the mobilisation of resources for the benefit of the palatial elite and its officers and servants, but there is circumstantial evidence that mobilisation was combined with a different form of pooling - the provision of subsistence relief. ${ }^{176}$ 
The picture of palatial economy which is beginning to emerge is a complex one: centrally directed economic activity co-existed with a non-palatial sector, redistribution with reciprocity and exchange (not true market exchange), and staple finance with wealth finance. As in the Near East, recent emphasis on the redistributive nature of Bronze Age economy must be modified, ${ }^{177}$ though this should not be taken as licence to return to modern capitalist commerce as a model for the Aegean palaces. ${ }^{178}$

This paper has principally been concerned with reconstructing palatial economy, that is with identifying the direction, content and institutional context of transactions involving the palace. In conclusion, brief consideration will be given to the significance of these transactions.

Palatial economic activity was to a large extent directed to the manufacture of fine craft goods and these in turn were used to acquire exotic raw materials (for further craft production) and to draw in staple resources from the local nonpalatial sector of the economy. On the one hand, this upwards mobilisation of resources financed the palatial elite. On the other hand, the authority of the palace was reinforced by the exaction of taxes and was legitimated by three types of activity financed by palatial mobilisation - the performance of ritual, the giving of craft goods to reward service and the exchange of prestige goods as diplomatic gifts with foreign elites.

Viewed from the bottom upwards, rather than top downwards, palatial mobilisation may also be seen in a rather different light. The palace provided its subject population with a source of subsistence relief in the event of shortage, with an opportunity to 'bank' unwanted surpluses and perhaps even with an incentive to increased production over normal subsistence needs. Palatial craft goods presumably circulated also within the non-palatial sector, being used to cement social alliances, to negotiate status and as tokens of value in the exchange of staples. ${ }^{179}$ In this respect, the palaces fulfilled a similar role to that played more recently by the market. In good years, recent Greek farmers have used the market to convert surplus staples or labour to the alternative (more durable or more exchangeable) form of livestock, land, money or consumer goods. These resources have been converted back to necessities in bad years. ${ }^{180}$ Late Bronze Age long-distance trade both secured raw materials for making tokens of value and served as an outlet for these tokens, and so inter alia played a regulatory function akin to the role of the international banking system and gold standard today. ${ }^{181}$

The Mycenaean palaces were complex and multi-faceted institutions, fulfilling a number of functions. A full understanding of these institutions requires an exploration both of those functions which are expressly revealed in the palatial archives and of others which are not. To this end, some striking lacunae in the archives, exposed by consideration of archaeological evidence and of recent rural economy, have proved almost as informative as the Linear B texts themselves. 


\section{NOTES}

1. The ultimate inspiration for this attempt to integrate written and material sources comes from the teaching of the late David Clarke. Particular thanks are due to John Killen for many years of patient advice on the mysteries of Linear B and Anthony Snodgrass for similar archaeological guidance. I am indebted to Gordon Hillman for advice on harvest scheduling and for sharing the results of his unpublished study of the Mycenae grain. For critical comments on earlier drafts of this paper, I am grateful to John Bennet, Keith Branigan, Yannis Hamilakis, Glynis Jones, John Killen, Chris Mee, Anthony Snodgrass and Tania Valamoti. John Cherry kindly pointed out that the original title of this paper contravened the Trade Descriptions Act!

2. Finley 1957, 135.

3. Polanyi 1957, 253-4; Killen 1985, 285.

4. E.g. Finley 1957; Polanyi 1960.

5. Renfrew 1972.

6. Cf. Earle 1977.

7. The form of redistribution envisaged for the Greek palaces by Renfrew (1972), in arguing that the heterogeneous environment of southern Greece favoured local agricultural specialisation and that the palatial elite emerged as redistributors of local products.

8. E.g. Cherry 1978; Gilman 1981; Renfrew 1982.

9. E.g. Earle 1977, 226; Earle and d'Altroy 1982, 271; Killen 1985, 284.

10. E.g. Halstead and O'Shea 1982.

11. Polanyi 1960.

12. Brumfiel and Earle 1987.

13. De Fidio 1982.

14. Killen 1985, 284-5 n. 39.

15. E.g. Sahlins 1974; O’Shea 1981.

I6. Finley 1957, 135.

17. E.g. Blanton et al. 1981; Brumfiel and Earle 1987, 4.

18. Renfrew 1982; Gamble 1982.

19. Brumfiel and Earle 1987, 6; Hicks 1969, 21; also (for Late Bronze Age Greece) Halstead 1981a, 332-3; Watrous 1984; cf. de Fidio 1987, 143.

20. Allan 1965; Halstead 1989.

21. E.g. Renfrew 1972; 1982.

22. Renfrew 1972.

23. Renfrew 1982.

24. Halstead in press a.

25. Also Bennet 1988, 22-5.

26. The Linear B archives are thus much narrower in scope than many of their Near Eastern counterparts - Finley 1957. 
27. De Fidio 1982; Killen 1985, 270-1. The commodities listed are associated with a-pu-do-si or some part of the verb (amo) $\delta i \delta \omega \mu$, implying the fulfilment of obligatory payments - cf. Lejeune 1975.

28. Killen 1983a; Uchitel 1984a.

29. Wyatt 1966; Shelmerdine 1973; Olivier 1974; Lejeune 1979; de Fidio 1982.

30. De Fidio 1982, 132-3. Even to the point that specialised metal-workers were taxed in hides and cloth-Lejeune 1979, 149.

31. Lejeune 1975, 2.

32. Foster 1981; Killen 1985, 247.

33. The quantities exacted only account for a small fraction of the land allocated and so probably represent a tax rather than direct palace involvement in the cultivation of these plants Foster 1977.

34. Lejeune 1979, 149; also Morris 1986, 108.

35. Chadwick 1972, 102; McDonald and Hope Simpson 1972, 141.

36. Lejeune 1979.

37. Olivier 1974.

38. Lejeune 1975; also (on Thebes) Killen 1979a, 176.

39. Ventris and Chadwick 1973, 195-213.

40. Killen 1964.

41. Killen 1964, 5 n. 23; Olivier 1967, 80.

42. Olivier $1967,80$.

43. Killen 1964.

44. Ventris and Chadwick 1973, 131.

45. Godart 1968; Cremona 1982.

46. G. Jones 1984.

47. Halstead in press a.

48. This conclusion is equally valid if the identifications of Linear B 'wheat' and 'barley' are reversed (cf. Ventris and Chadwick 1973, 130) and is not significantly weakened if rare occurrences of 'flour' refer to bread wheat and not to a particular form of processed cereal (e.g. Cremona 1982, 73 n. 1).

49. This is particularly obvious in the case of plots planted in fruit trees - Duhoux 1974; also Killen 1987.

50. Godart 1968; Cremona 1982, 76-8.

51. Ventris and Chadwick 1973, 272-4; Hiller 1983; Killen 1987.

52. Godart 1968. The association may also indicate that, while figs and vines were grown in dedicated orchards, olives were intercropped with cereals - Hiller 1983, 175-6.

53. Around Pylos itself and, on Crete, around Knossos itself, Dawo (near the major sub-centre and once independent palace of Phaistos), Kydonia etc. - Killen 1985, 278-9; 1987, 177; Hiller 1988, 61; de 
Fidio 1987; Bennet 1985, 246. The palace exploited more distant land-holdings indirectly, by levying taxes in 'cash-crops' such as flax.

54. Killen 1984a, 58 n. 2.

55. Finley 1957, 139; Killen 1985, 244-6. Contributions in kind might also be levied on land so allocated - Killen 1979b; Foster 1981

56. Hiller 1988, 53-68; Chadwick 1988.

57. Killen 1985, 288 n. 47; de Fidio 1982, 134.

58. E.g. Killen 1985, 285-6; 1979a.

59. Killen 1985, 272-3.

60. Morpurgo Davies 1979. On the identification of kúavo $\varsigma$ as glass-paste-Ventris and Chadwick 1973,340 .

61. Killen 1985, 253-4.

62. E.g. Chadwick 1985.

63. De Fidio 1977.

64. E.g. oxen - Palaima 1989.

65. Chadwick 1985, 200: 'The concentration of records in the palace clearly demonstrates that the secular power was dominant over the religious.'

66. Cf. Killen 1985, 289: 'these religious interests are not only recorded by the palace, but are treated by it in precisely the same way as its "own" interests'.

67. Chadwick 1985, 200; sacrifices, which are not specified but are implied by records of fattened oxen and pigs (Palaima 1989), could also have contributed to the maintenance of religious specialists.

68. Chadwick 1985, 198, 200; Killen 1985, 295 n. 89; Shelmerdine 1985, 42; Tegyey 1984. At Knossos, a scribal office overseeing the manufacture of perfumed oil also administered the issuing of religious offerings - Foster 1977 .

69. Hiller 1988.

70. De Fidio 1982, 134-5.

71. Chadwick 1985, 201; Halstead in prep., on the faunal remains from excavations directed by $\mathbf{J}$. Wright at Nemea-Tsoungiza.

72. Killen 1984b.

73. E.g. Killen 1963, 81. Rations were often issued on a monthly or daily basis (Chadwick 1988, 73-4) and some obligations to the palace seem to have been exacted on a three-yearly cycle (de Fidio 1977).

74. Finley 1957, 135; Killen 1985, 265; Palaima 1991.

75. Killen 1985, 263-4.

76. E.g. Blegen and Rawson 1966; Iakovidis 1977.

77. Room 55-Blegen and Rawson 1966, 224; North-east workshop-Tegyey 1984; Morris 1986, 134; Court 47-Shelmerdine 1985, 61.

78. House of Columns/Artisans-Mylonas 1966; Sakellarakis 1979, 17; Tournavitou 1988; Citadel House - Taylour 1969; Sakellarakis 1979, 19; House of Shields and House of Sphinxes - Sakellarakis 
1979, 21-39. For the production of glass ornaments at Mycenae and Knossos, see Higgins 1980, 78 82; Foster 1979, 6. It is unclear where perfume was produced at Mycenae-Shelmerdine 1985, 53-5.

79. Demakopoulou 1990; House of Kadmos-Keramopoullos 1930; Kordatzis and Koropoulis plots - Demakopoulou and Konsola 1981, 24, 50, 56; Tournavitou 1988.

80. Warren 1967; Younger 1979.

81. E.g. Cavanagh and Mee 1990, 57 Table 1, 59 Table 3.

82. For the argument that chamber tombs catered for more than the upper echelons of Mycenaean society, see Mee and Cavanagh 1984.

83. E.g. found at almost all Mycenaean sites (particularly tombs) in Attica - Stubbings 1947, 14, 24.

84. Cook 1981; Shelmerdine 1985, 142-5.

85. Stubbings 1951; Shelmerdine 1985, 142; for archaeometric confirmation that most 'Mycenaean' fine ware vessels in the east Mediterranean were made in southern mainland Greece, see R. E. Jones $1986,542-71$.

86. Wiener 1991, 329.

87. Wright 1984, 23.

88. E.g. Palaima 1989, 95.

89. Halstead in press a.

90. Shelmerdine 1981; Halstead in press a; Halstead in prep. (n. 71).

91. In the case of Pylos, perhaps as little as $8 \%$ of the population and recorded land-holders well under 1\%-Hiller 1988, 61-3. Moreover, many palatial 'dependents' were probably fulfilling parttime obligations of service.

92. E.g. Gale 1991.

93. Catling et al. 1980; Riley 1981. Also Shelmerdine 1985, 142-5; Haskell 1984.

94. Keramopoullos 1930; Alexiou 1961; Killen 1985, 268; Wiener 1991; cf. Warren 1991. For Linear B evidence that the so-called merchants' houses outside the acropolis at Mycenae were palace offices, see Killen 1983b.

95. Peltenberg 1991, 168.

96. E.g. Bass 1967; 1986. The ton of copper carried on the Gelidonya vessel is equivalent to the weight of bronze recorded in the Pylos archives - Killen 1985, 266; the Ulu Burun ship carried five times the weight of bronze recorded at Pylos-Snodgrass 1991, 18.

97. Hankey 1980.

98. Cherry 1986; Cavanagh and Laxton 1981; also Ventris and Chadwick 1973, 110.

99. Cf. Zaccagnini 1987, 59-60. For possible exchanges of this type between Greece and the east Mediterranean, see Peltenberg 1991.

100. Palaima and Wright 1985.

101. Blegen and Rawson 1966, 102, 105.

102. Or feasting-Morris 1986, 141-4.

103. Indeed, in addition to control by higher palatial officials, some industrial work groups seem to have included a low-ranking supervisor (in receipt of $D A$ or $T A$ ration supplements)-Killen 1968. 
104. Bennet $1988,37-40$.

105. Halstead 1981b; Moody 1987; Branigan 1987; 1988.

106. E.g. Wright 1984; also Killen 1984a, 53-61.

107. Halstead 1987; Halstead and Jones 1989.

108. Halstead 1981a; in press b.

109. Halstead in press a.

110. Hillman in press; pers. comm. But see Halstead in press a, n. 117, for a cautionary note on this writer's use of Hillman's observations.

111. G. Jones in press.

112. Most published archaeobotanical reports amalgamate the data from coeval samples, preventing analysis of the association between particular crops and particular weeds and indeed making it impossible to determine whether wild species have arrived on site as crop weeds.

113. E.g. Bayliss-Smith 1982.

114. Duhoux 1974, 28.

115. E.g. Halstead 1987, $84 \mathrm{n}$. 49. Cf. the suggestion of a normative allocation of land for the support of an individual family of $D A 1$ (ca. 0.5 ha.)-Duhoux 1974,37; in the recent past, holdings of this size have typically been worked by hand-Halstead 1987, 84 n. 49 .

116. Ventris and Chadwick 1973, 212.

117. Although the palace retained the services of a large number of ox-herds, arguably exceeding the number needed to look after bulls destined for sacrifice-Palaima 1989, 100, 115.

118. De Fidio 1977.

119. Allowing ca. 5 ha. of winter cereals (plus 5 ha. of fallow) per pair of oxen - Halstead 1987, $84 \mathrm{n}$. 49; unpublished field notes. There is circumstantial Linear B evidence for the same relationship of 2 oxen : 5 ha. (10 GRA) - de Fidio 1982, 124.

120. Halstead 1987, 82; Halstead and Jones 1989, 49-50.

121. Olivier $1967,86$.

122. E.g. Halstead in press $\mathrm{c}$.

123. Godart 1968, 60. The association between cereals and olives is further underlined by that between figs and vines in orchard records-Hiller 1983, 176.

124. E.g. Forbes 1982.

125. Chadwick 1976, 117-18.

126. Halstead 1981a, 318; for comparable figures arrived at by a different route, see Duhoux 1974, 33.

127. Above (n. 119).

128. By way of comparison, the average extent of 54 'chiflik' estates in Thessaly, expropriated by the Greek state between 1907 and 1914, was ca. 2,000 ha. and individual estates of ca. 500 ha. seem to have been commonplace in the early twentieth century-Vergopoulos 1975, 169, 178. A 'typical' wheat-producing estate in seventeenth-century Macedonia covered ca. 500 ha. of cultivated land and was worked by ca. 50 ploughmen-Moskof 1979, 60-2.

129. The absence of records of assessments and deficits (Godart 1968) precludes a fixed-sum tax. 
130. The Mesara plain covers 22,500 ha. - Duhoux 1974, 33. For the prevalence of the one-tenth tax in antiquity, see A. H. M. Jones 1974, 178.

131. Implausible both because of the distances involved and because of the existence of other subcentres where much of this produce could more easily have been collected. Conversely, a tithe levied on all non-palatial grain crops but paid in 'wheat' would have demanded complex administrative procedures of which there is no trace in the archives.

132. Further such estates may be indicated by Knossos records of groups of working oxen at secondand third-order centres in central and western Crete-Bennet 1985, 246.

133. At 0.05 ha. per man-day. With modern iron sickles, a rate of $0 . I$ ha. per man-day may be optimistic-Halstead and Jones 1989, 47; Halstead unpublished field notes; experimental data suggest a much slower rate of ca. 0.1 ha per 20 man-hours with primitive bronze sickles - Russell 1988,116 Table 20 .

134. These costs are more variable than those of reaping: transport costs depend on the distance between field and place of storage, while the labour costs of winnowing and threshing depend on the availability of suitable weather - Halstead and Jones 1989, 47-9.

135. The palace at Knossos recorded the issuing of rations to at least 2,000 persons and received enough grain to support at least 4,000 persons year round-Godart 1968,63. Note that the figure of 20,000 man-days does not include the labour costs of transporting and processing the Dawo crop, or of harvesting on any other palatial estates.

136. Halstead in press a; Uchitel 1984a.

137. Killen 1963, 87.

138. Killen 1963, 88.

139. Olivier 1967, 81-2.

140. Olivier 1967,82 n. 21.

141. On the $100 \%$ lambing rate expected in the Knossos 'Dl' lambing records-Killen 1963, 78.

142. Killen $1964,13 \mathrm{n}$. $63 \mathrm{~b}$; cf. an estimated $80 \%$ survival rate for other wool flock records at Knossos - Olivier 1967, 80.

143. See Killen 1963 for the meaning of $o$ and $p a$.

144. Killen 1963, 89; Olivier 1967, 83 n. 21; Olivier 1988.

145. Godart 1977, 39-40.

146. Godart 1977, 36-8.

147. E.g. Palaima 1989, $104-10$; Killen in press a.

148. Forbes 1982; 1976; 1989; Halstead 1990; Gallant 1991.

149. Bio-archaeological evidence suggests diversity in both crops and livestock at a site level, but there is little information available at the level of the individual household -Halstead in press a.

150. Chang and Koster 1986.

151. Killen 1985, 252.

152. Godart 1968, 62 .

153. Dahl and Hjort 1976; Redding 1984. Lean meat is of negligible (or even negative) value as a famine food - Speth and Spielmann 1983. 
154. Dahl and Hjort 1976, 220. This figure ignores the size, age, sex and nutritional status of the sheep concerned, but may suffice for an order-of-magnitude estimate.

155. Cf. suggestions that underground storage silos ('koulouras') at the early (Minoan) palaces of Knossos and Phaistos could have held enough grain to provide one year's subsistence for 800 and 300 persons respectively - Branigan 1987; Wiener 1991, 332 and 342 n. 6.

156. E.g. dependent workers described as do-e-ro/do-e-ra (who could be bought) may by analogy with Near Eastern archives have been such 'depressed' members of society - Killen 1979b.

157. Chadwick $1988,90$.

158. For other possible payments in kind, see Killen 1988,183 n. 36.

159. Hiller 1988, 61. The few 'shepherds' with land allocations recorded in the Pylos archive perhaps played a supervisory role - Foster 1981, 98-106.

160. E.g. the normal lambing target of 1 lamb/ewe/year (Killen 1963, 78) is likely to have been met only in good years.

161. There are also possible indications at Pylos that herding 'contracts' were renewed annually (Killen in press b), in contrast with the apparently longer-term relationship between the palace and other categories of dependent personnel, such as groups of women with children-Chadwick 1988; Hiller 1988; Killen 1966; 1981; cf. de Fidio 1987, 138; Uchitel 1984b.

162. Keramopoullos 1930; Renfrew 1972, 472; Killen 1985, 262-3; Zaccagnini 1987; cf. Snodgrass 1991, 16-17; Peltenberg 1991.

163. Hiller 1988; Killen 1985, 244; Lejeune 1975, 2; Foster 1981; Killen 1983a.

164. Killen 1988, 181-3.

165. Godart et al. 1979.

166. E.g. Killen 1984b.

167. This interpretation is consistent with the content of the extant 'purchase' documents, which detail the amounts of each commodity to be paid out, but only record the identity (not quantity) of the commodity purchased. For a discussion of the movement of scribes and records within the palace at Pylos, see Palaima and Wright 1985.

168. Mikhailidhou 1990.

169. Lejeune 1979, 149.

170. For example, the implied exchange rates between grain, sheep, cattle and bronze are paralleled both in the bronze age Near East and in early historical Greece and Rome-de Fidio 1982.

171. Deficits were separately recorded for each taxed commodity, and there is no indication that a shortfall in one commodity could be made up by an extra contribution in another-Killen 1984b.

172. Polanyi 1957, 254-5; Renger 1984.

173. More marked in the case of Pylos than of Knossos-Killen 1984a, 53-61.

174. Cf. Earle and d'Altroy 1982.

175. Above (n. 30); also Godart 1977, 38; Bennet 1985, 240; Killen 1984a, 55-60; Halstead in press a; pace Palaima 1989, 114.

176. Also some evidence that, through the second millennium BC, mobilisation increased in importance at the expense of the provision of subsistence relief -above (n. 105). 
177. Also Sherratt and Sherratt 1991, 352-3.

178. Cf. Warren 1991.

179. Cf. O'Shea 1981.

180. Halstead 1990.

181. Cf. O'Shea 1981, esp. 178-9. The qualitative importance of long-distance trade, for the supply of prestige goods (Sherratt and Sherratt 1991) and exchangeable tokens, is not in conflict with the argument that such exchange was quantitatively of limited significance (Snodgrass 1991) and afforded few opportunities for independent merchants (cf. Warren 1991).

\section{BIBLIOGRAPHY}

Alexiou, S. (1961) 'Zitimata tou proïstorikou viou: kritomikinaïkon emborion', $A E$ 1953-4, 135-45. Allan, W. (1965) The African husbandman.

Bass, G. F. (1967) 'Cape Gelidonya: a bronze age shipwreck', TAPhS 57(8).

(1986) 'A bronze age shipwreck at Ulu Burun (Kas): 1984 campaign', $A J A$ 90, 269-96.

Bayliss-Smith, T. (1982) The ecology of agricultural systems.

Bennet, J. (1985) 'The structure of the Linear B administration at Knossos', AJA 89, 231-49.

(1988) "Outside in the distance": problems in understanding the economic geography of Mycenaean palatial territories', in J.-P. Olivier and T. G. Palaima (eds.), Texts, tablets and scribes 19-41.

Blanton, R. E., Kowalewski, S. A., Feinman, G. and Appel, J. (1981) Ancient Mesoamerica: a comparison of change in three regions.

Blegen, C. W. and Rawson, M. (1966) The palace of Nestor at Pylos in western Messenia. 1: The buildings and their contents.

Branigan, K. (1987) 'The economic role of the first palaces', in R. Hägg and N. Marinatos (eds.), The function of the Minoan palaces 245-8.

(1988) 'Some observations on state formation in Crete', in E. B. French and K. A. Wardle (eds.), Problems in Greek prehistory 63-71.

Brumfiel, E. and Earle, T. (1987) 'Specialisation, exchange and complex societies: an introduction', in E. Brumfiel and T. Earle (eds.), Specialisation, exchange and complex societies 1-9.

Catling, H. W., Cherry, J. F., Jones, R. E. and Killen, J. T. (1980) 'The Linear B inscribed stirrup jars and west Crete', $A B S A$ 75, 49-113.

Cavanagh, W. and Laxton, R. (1981) 'The structural mechanics of the Mycenaean tholos tomb', ABSA 76, 109-40.

Cavanagh, W. G. and Mee, C. (1990) 'The location of Mycenaean chamber tombs in the Argolid', in R. Hägg and G. C. Nordquist (eds.), Celebrations of death and divinity in the bronze age Argolid $55-63$.

Chadwick, J. (1972) 'The Mycenaean documents', in W. A. McDonald and G. R. Rapp (eds.) The Minnesota Messenia expedition 100-16.

(1976) The Mycenaean world.

(1985) 'What do we know about Mycenaean religion?', in A. Morpurgo Davies and Y. Duhoux (eds.), Linear B: a 1984 survey 191-202.

(1988) 'The women of Pylos', in J.-P. Olivier and T. G. Palaima (eds.), Texts, tablets and scribes 43-93.

Chang, C. and Koster, H. (1986) 'Beyond bones: toward an archaeology of pastoralism', in M. Schiffer (ed.), Advances in archaeological method and theory 9 97-148.

Cherry, J. F. (1978) 'Generalization and the archaeology of the state', in D. Green, C. Haselgrove and M. Spriggs (eds.), Social organisation and settlement (BAR Int. Series 47) 411-37.

(1986) 'Polities and palaces: some problems in Minoan state formation', in C. Renfrew and J. F. Cherry (eds.), Peer polity interaction 1945.

Cook, K. 1981. 'The purpose of the stirrup vase', $A B S A 76,167$.

Cremona, M. V. (1982) 'I cereali nelle tavolette in Lineare B di Cnosso', SMEA 23, 73-82. 
Dahl, G. and Hjort, A. (1976) Having herds: pastoral herd growth and household economy.

Demakopoulou, K. (1990) 'Palatial and domestic architecture in Mycenaean Thebes', in P. Darque and R. Treuil (eds.), L'Habitat Égéen préhistorique 307-17.

Demakopoulou, K. and Konsola, D. (1981) Archaeological museum of Thebes.

Duhoux, Y. (1974) 'Les mesures mycéniennes de surface', Kadmos 13, 27-38.

Earle, T. K. (1977) 'A reappraisal of redistribution: complex Hawaiian chiefdoms', in T. K. Earle and J. E. Ericson (eds.), Exchange systems in prehistory 213-29.

Earle, T. K. and d'Altroy, T. (1982) 'Storage facilities and state finance in the upper Mantaro valley, Peru', in J. E. Ericson and T. K. Earle (eds.), Contexts for prehistoric exchange 265-90.

de Fidio, P. (1977) I dosmoi pilii a Poseidon (Incunabula Graeca 65).

(1982) 'Fiscalita, redistribuzione, equivalenze: per una discussione sull economia micenea', $S M E A$ 23, 83-136.

(1987) 'Palais et communautés de village dans le royaume mycénien de Pylos', in P. Ilievski and L. Crepajac (eds.), Tractata Mycenaea 129-49.

Finley, M. I. (1957) 'The Mycenaean tablets and economic history', Economic History Review 10, $128-41$.

Forbes, H. (1976) " "We have a little of everything": the ecological basis of some agricultural practices in Methana, Trizinia', Annals of the New York Academy of Sciences 268, 236-50.

(1982) Strategies and soils: technology, production and environment in the peninsula of Methana, Greece, $\mathrm{Ph}$.D. dissertation, University of Pennsylvania.

(1989) 'Of grandfathers and grand theories: the hierarchised ordering of responses to hazard in a Greek rural community', in P. Halstead and J. O'Shea (eds.), Bad year economics 87-97.

Foster, E. D. (1977) 'An administrative department at Knossos concerned with perfumery and offerings', Minos 16, 19-51.

(1981) 'The flax impost at Pylos and Mycenaean landholding', Minos 17, 67-121.

Foster, K. P. (1979) Aegean faience of the Bronze Age.

Gale, N. H. (ed.) (1991) Bronze age trade in the Mediterranean.

Gallant, T. W. (1991) Risk and survival in ancient Greece.

Gamble, C. (1982) 'Leadership and "surplus" production', in C. Renfrew and S. Shennan (eds.), Ranking, resource and exchange 100-5.

Gilman, A. (1981) 'The development of social stratification in bronze age Europe', Current Anthropology 22, 1-8.

Godart, L. (1968) 'Le grain à Cnossos', SMEA 5, 5663.

(1977) 'Les ressources des palais mycéniens de Cnossos et Pylos, $L E C$ 45, 31-42.

Godart, L., Killen, J. T. and Olivier, J.-P. (1979) 'Un sixième fragment de tablette en Lineaire B de Tirynthe', $A A$ 450-8.

Halstead, P. (1981a) 'Counting sheep in neolithic and bronze age Greece', in I. Hodder, G. Isaac and N. Hammond (eds.), Pattern of the past: studies in honour of David Clarke 307-39.

(198lb) 'From determinism to uncertainty: social storage and the rise of the Minoan palace', in A. Sheridan and G. Bailey (eds.), Economic archaeology 187-213.

(1987) 'Traditional and ancient rural economy in Mediterranean Europe: plus ça change?', JHS $107,77-87$.

(1989) 'The economy has a normal surplus: economic stability and social change among early farming communities of Thessaly, Greece', in P. Halstead and J. O'Shea (eds.), Bad year economics $68-80$.

(1990) 'Waste not, want not: traditional responses to crop failure in Greece', Rural History: Economy, Society, Culture 1,147-64.

In press a. 'Agriculture in the bronze age Aegean: towards a model of palatial economy', in B. Wells (ed.), Agriculture in ancient Greece 105-117.

In press b. 'The North-South divide: regional paths to complexity in prehistoric Greece', in C. Mathers and S. Stoddart (eds.), Development and decline in the bronze age Mediterranean.

In press c. 'Present to past in the Pindhos: specialisation and diversification in mountain economies', Rivista di Studi Liguri 56, 61-80.

Halstead, P. and Jones, G. (1989) 'Agrarian ecology in the Greek islands: time stress, scale and risk', JHS 109, 41-55. 
Halstead, P. and O'Shea, J. (1982) 'A friend in need is a friend indeed: social storage and the origins of social ranking', in C. Renfrew and S. Shennan (eds.), Ranking, resource and exchange 92-9.

Hankey, V. (1980) 'The Aegean interest in el Amarna', Journal of Mediterranean Anthropology and Archaeology 1, 38-49.

Haskell, H. W. (1984) 'Pylos: stirrup jars and the international oil trade', in T. G. Palaima and C. W. Shelmerdine (eds.), Pylos comes alive 97-107.

Hicks, J. (1969) A theory of economic history.

Higgins, R. A. (1980) Greek and Roman jewellery, ed. 2.

Hiller, S. (1983) 'Fruchtbaumkulturen auf Kreta und in Pylos', in A. Heubeck and G. Neumann (eds.), Res Mycenaeae 171-201.

(1988) 'Dependent personnel in Mycenaean texts', in M. Heltzer and E. Lipinski (eds.), Society and economy in the eastern Mediterranean 53-68.

Hillman, G. C. in press. 'Ancient grain from the destruction of Mycenae citadel'.

Iakovidis, S. (1977) 'The present state of research at the citadel of Mycenae', BIAL 14, 99-141.

Jones, A. H. M. (1974) The Roman economy.

Jones, G. (1984) 'The LMII plant remains', in M. R. Popham, The Minoan Unexplored Mansion al Knossos 303-6.

In press. 'Weed phytosociology and crop husbandry: identifying a contrast between ancient and modern practice', in J.-P. Pals (ed.), Festschrift W. van Zeist.

Jones, R. E. (1986) Greek and Cypriot pottery: a review of scientific studies.

Keramopoullos, A. D. (1930) 'Ai viomikhaniai kai to emborion tou Kadhmou', $A E$ 29-58

Killen, J. T. (1963) 'Some adjuncts to the SHEEP ideogram on Knossos tablets', Eranos 61, 69-93.

(1964) 'The wool industry of Crete in the late bronze age', ABSA 59, 1-15.

(1966) 'The abbreviation $t u$ on Knossos tablets', ZAnt 16, 207-12.

(1968) 'The Knossos o-pi tablets', in Atti e memorie del 1 congresso internazionale di micenologia 636-43.

(1979a) 'The Knossos Ld(1) tablets', in E. Risch and H. Mühlestein (eds.), Colloquium Mycenaeum $151-79$.

(1979b) 'The Linear B tablets and economic history: some problems', BICS 26, 133-4.

(1981) 'Some puzzles in a Mycenae personnel record', ZAnt 31, 37-45.

(1983a) 'PY An 1', Minos 18, 71-9.

(1983b) 'On the Mycenae Ge tablets', in A. Heubeck and G. Neumann (eds.), Res Mycenaeae 216-32.

(1984a) 'The textile industries at Pylos and Knossos', in T. G. Palaima and C. W. Shelmerdine (eds.), Pylos comes alive 49-63.

(1984b) 'Last year's debts on the Pylos Ma tablets', SMEA 25, 173-88.

(1985) 'The Linear B tablets and the mycenaean economy', in A. Morpurgo Davies and Y. Duhoux (eds.), Linear B: a 1984 survey 241-305.

(1987) 'Piety begins at home: place-names on Knossos records of religious offerings', in P. Ilievski and L. Crepajac (eds.), Tractata Mycenaea: proceedings of the eighth international colloquium on Mycenaean studies 163-77.

(1988) 'Epigraphy and interpretation in Knossos WOMAN and CLOTH records', in J.-P. Olivier and T. G. Palaima (eds.), Texts, tablets and scribes 167-83.

In press a. 'Thebes sealings and Knossos tablets', in Atti del ii congresso internazionale di micenologia.

In press b. 'Sheep at Knossos and Pylos', Bulletin on Sumerian Agriculture.

Lejeune, M. (1975) ' $\triangle \mathrm{O} \Sigma \mathrm{MO} \Sigma$ et AПY $\triangle \mathrm{O} \Sigma \mathrm{I} \Sigma$ ', $M H$ 32(1), 1-11.

(1979) 'Sur la fiscalité pylienne Ma', in E. Risch and H. Mühlestein (eds.), Colloquium Mycenaeum $147-50$.

McDonald, W. A. and Hope Simpson, R. (1972) 'Archaeological exploration', in W. A. McDonald and G. R. Rapp (eds.) The Minnesota Messenia expedition 117-47.

Mee, C. B. and Cavanagh, W. G. (1984) 'Mycenaean tombs as evidence for social and political organisation', Oxford Journal of Archaeology 3, 45-64.

Mikhailidhou, A. (1990) 'Metriko sistima kai skhesis paragogis sto Aigaio, stin isteri epokhi tou khalkou', Meletimata tou K.E.R.A. 10, 6596. 
Moody, J. (1987) 'The Minoan palace as a prestige artefact', in R. Hägg and N. Marinatos (eds.), The function of the minoan palaces $235-41$.

Morpurgo Davies, A. (1979) 'Terminology of power and terminology of work in Greek and Linear B', in E. Risch and H. Mühlestein (eds.), Colloquium Mycenaeum 87-108.

Morris, H. J. (1986) An economic model of the late Mycenaean kingdom of Pylos, Ph.D. dissertation, University of Minnesota.

Moskof, K. (1979) Istoria tou kinimatos tis ergatikis taxis.

Mylonas, G. E. (1966) 'The east wing of the palace of Mycenae', Hesperia 35, 419-26.

Olivier, J.-P. (1967) 'La série Dn de Cnossos', SMEA 2, 71-93.

(1974) 'Une loi fiscale mycénienne', $B C H$ 98, 23-35.

(1988) 'KN: Da-Dg', in J.-P. Olivier and T. G. Palaima (eds.), Texts, tablets and scribes 219-67.

O'Shea, J. (1981) 'Coping with scarcity: exchange and social storage', in A. Sheridan and G. Bailey (eds.), Economic archaeology (BAR Int Series 96) 167-83.

Palaima, T. G. (1989) 'Perspectives on the Pylos oxen tablets: textual (and archaeological) evidence for the use and management of oxen in late bronze age Messenia (and Crete'), Studia Mycenaea 1988 85-124.

(1991) 'Maritime matters in the Linear B tablets', in R. Laffineur and L. Basch (eds.), Thalassa: l'Egée préhistorique et la mer (Aegaeum 7) 273-310.

Palaima, T. G. and Wright, J. C. (1985) 'Ins and outs of the archive rooms at Pylos: form and function in a Mycenaean palace', $A J A 89,251-62$.

Peltenberg, E. (1991) 'Greeting gifts and luxury faience: a context for orientalising trends in late Mycenaean Greece', in N. H. Gale (ed.), Bronze age trade in the Mediterranean 162-79.

Polanyi, K. (1957) 'The economy as instituted process', in K. Polanyi, C. M. Arensberg and H. W. Pearson (eds.), Trade and market in the early empires 243-70.

(1960) 'On the comparative treatment of economic institutions in antiquity with illustrations from Athens, Mycenae, and Alalakh', in C. H. Kraeling and R. M. Adams (eds.), City invincible 329-50.

Redding, R. W. (1984) 'Theoretical determinants of a herder's decisions: modeling variation in the sheep : goat ratio', in J. Clutton-Brock and C. Grigson (eds.), Animals and archaeology 3: early herders and their flocks (BAR Int. Series 202) 223-41.

Renfrew, C. (1972) The emergence of civilisation: the Cyclades and the Aegean in the third millennium $B C$.

(1982) 'Polity and power', in C. Renfrew and M. Wagstaff (eds.) An island polity: the archaeology of exploitation in Melos 264-90.

Renger, J. (1984) 'Patterns of non-institutional trade and non-commercial exchange in ancient Mesopotamia at the beginning of the second millennium BC', in A. Archi (ed.), Circulation of goods in non-palatial context in the ancient Near East 31-123.

Riley, J. A. (1981) 'Petrological examination of coarse-ware stirrup-jars from Mycenae', ABSA 76, $335-40$.

Russell, K. W. (1988) After Eden: the behavioral ecology of early food production in the Near East and North Africa (BAR Int. Series 391).

Sahlins, M. (1974) Stone age economics.

Sakellarakis, J. (1979) To elefantodonto kai i katergasia tou sta mikinaika khronia.

Shelmerdine, C. W. (1973) 'The Pylos Ma tablets reconsidered', AJA 77, 261-75.

(1981) 'Nichoria in context: a major town in the Pylos kingdom', $A J A$ 85, 319-25.

(1985) The perfume industry of Mycenaean Pylos.

Sherratt, A. and Sherratt, S. (1991) 'From luxuries to commodities: the nature of Mediterranean bronze age trading systems', in N. H. Gale (ed.), Bronze age trade in the Mediterranean 351-86.

Snodgrass, A. M. (1991) 'Bronze age exchange: a minimalist position', in N. H. Gale (ed.), Bronze age trade in the Mediterranean 15-20.

Speth, J. and Spielmann, K. (1983) 'Energy source, protein metabolism and hunter-gatherer subsistence strategies', Journal of Anthropological Archaeology 2, 1-31.

Stubbings, F. H. (1947) 'The Mycenaean pottery of Attica', ABSA 42, 1-75.

(1951) Mycenaean pottery from the Levant.

Taylour, W. (1969) 'Mycenae, 1968', Antiquity 43, 91-7. 
Tegyey, I. (1984) 'The northeast workshop at Pylos', in T. G. Palaima and C. W. Shelmerdine (eds.), Pylos comes alive 65-79.

Tournavitou, I. (1988) 'Towards an identification of a workshop space', in E. B. French and K. A. Wardle (eds.), Problems in Greek prehistory 447-67.

Uchitel, A. (1984a) 'On the "military" character of the $o-k a$ tablets', Kadmos 23, 136-63.

(1984b) 'Women at work: Pylos and Knossos, Lagash and Ur', Historia 33, 257-82.

Ventris, M. and Chadwick, J. (1973) Documents in Mycenaean Greek ed. 2.

Vergopoulos, K. (1975) To agrotiko zitima stin Elladha.

Warren, P. (1967) 'A stone vase-maker's workshop in the palace at Knossos', ABSA 62, 195-201.

(1991) 'A merchant class in bronze age Crete', in N. H. Gale (ed.), Bronze age trade in the Mediterranean 295-301.

Watrous, L. V. (1984) 'Ayia Triada: a new perspective on the Minoan villa', $A J A$ 88, 123-34.

Wiener, M. (1991) 'The nature and control of Minoan foreign trade', in N. H. Gale (ed.), Bronze age trade in the Mediterranean 325-50.

Wright, J. (1984) 'Changes in form and function of the palace at Pylos', in T. G. Palaima and C. W. Shelmerdine (eds.), Pylos comes alive 19-29.

Wyatt, W. F. (1966) 'The Ma tablets from Pylos', $A J A$ 62, $21-41$.

Younger, J. G. (1979) 'The lapidary's workshop at Knossos', ABSA 74, 258-68.

Zaccagnini, C. (1987) 'Aspects of ceremonial exchange in the Near East during the late second millenium BC', in M. Rowlands, T. M. Larsen and K. Kristiansen (eds.), Centre and periphery in the ancient world 57-65. 